\title{
Kemampuan Berpikir Kritis Peserta Didik Dalam Model Pembelajaran (CUPs) Matematika SMK Negeri 1 Polewali
}

\author{
Muhammad Assaibin, ${ }^{1}$ Muhammad Ali $\mathrm{P}^{2}$, Ayu Rahayu ${ }^{3}$, Elviana ${ }^{4}$ \\ 1, 2,3,4 Pendidikan Matematika FKIP Universitas Al Asyariah Mandar, Jl. Budi Utomo No. 2 Manding Polewali Mandar, \\ Sulawesi Barat 91311 \\ muhammad.assaibin89@gmail.com
}

\begin{abstract}
This research is quasi-experimental research that aims to determine the Critical Thinking Ability of Students in Mathematics Learning. This research was taken from two research samples, namely class XII Adm. Office 1 which consists of 30 students and XII Adm. Office 2 with a total of 24 students. The instruments used in this study were tests of students' critical thinking skills, student activity sheets, learning implementation sheets, and student response questionnaires. Meanwhile, data collection was carried out using descriptive analysis techniques and inferential analysis. From the results of the statistical analysis of the pretest and post test, it shows that, each of the average values obtained shows that it is greater in the experimental class than in the control class. Meanwhile, judging from the activities of students and the implementation of learning, that through the CUPs learning model it is more effectively used in the experimental class. Meanwhile, judging from the responses of students, where students are more dominant in choosing positive responses with interpretation criteria almost all respond positively. While the calculation of the results of the t-test for posttest data, obtained a value of 2.524. Meanwhile, it is 1.697, which means that or $2.524>1.697$. From the results of the analysis. It can be seen that students' critical thinking skills using the CUPs learning model in mathematics learning for class XII SMK Negeri 1 Polewali.
\end{abstract}

Keywords: Ability, Critical Thinking, Learning Model (CUPs)

\begin{abstract}
Penelitian ini merupakan penelitian quasi eksperimen yang bertujuan untuk mengetahui Kemampuan Berpikir Kritis Peserta Didik dalam Pembelajaran Matematika. Penelitian ini diambil dari dua sampel penelitian, yaitu kelas XII Adm. Perkantoran 1 yang berjumlah 30 peserta didik dan XII Adm. Perkantoran 2 dengan jumlah 24 peserta didik. Instrumen yang digunakan pada penelitian ini adalah tes kemampuan berpikir kritis peserta didik, lembar aktivitas peserta didik, lembar keterlaksanaan pembelajaran, dan angket respon peserta didik. Sedangkan, pengumpulan data dilakukan dengan menggunakan teknik analisis deskriptif dan analisis inferensial. Dari hasil analisis statistikpre test dan post test menunjukkan bahwa, masing-masing nilai rata-rata yang diperoleh menujukkan lebih besar dikelas ekperimen daripada kelas kontrol. Sementara dilihat dari aktivitas peserta didik dan keterlaksanaan pembelajaran, bahwa melalui model pembelajaran CUPs lebih efektif digunakan pada kelas ekperimenp. Sedangkan dilihat dari respon peserta didik, dimana peserta didik lebih dominan memilih respon positif dengan kriteria penafsiran hampir seluruhnya merespon positif. Sementara perhitungan hasil uji t untuk data posttest, didapat nilai $t_{\text {hitung }}$ sebesar 2,524. Sedangkan $t_{\text {tabel }}$ sebesar 1,697, yang berarti bahwa $t_{\text {hitung }}>$ $t_{\text {tabel }}$ atau 2,524 > 1,697. Dari hasil analisis tersebut, terlihat kemampuan berpikir kritis peserta didik dengan menggunakan model pembelajaranCUPs dalam pembelajaran matematika kelas XII SMK Negeri 1 Polewali.
\end{abstract}

Kata Kunci: Kemampuan, Berpikir Kritis, Model Pembelajaran (CUPs).

Copyright (c) 2021 Muhammad Assaibin, Muhammad Ali P, Ayu Rahayu, Elviana

$\triangle$ Corresponding author: Muhammad Assaibin

Email Address: muhammad.assaibin89@gmail.com (Jl. Bina Widya Simpang Baru, Pekanbaru)

Received 23 July 2021, Accepted 18 August 2021, Published 17 September 2021

\section{PENDAHULUAN}

Pendidikan adalah suatu proses belajar mengajar tentang wawasan, kompetensi, dan kebiasaan serangkai manusia yang diturunkan dari generasi ke kegenerasi berikutnya melalui bimbingan, pelatihan, dan penelitian. Pendidikan berdasarkan bidangnya sendiri mempunyai banyak jenis, salah satunya pendidikan matematika. Matematika sendiri mempunyai fungsi yang hakiki dalam ilmu pendidikan, hingga suatu ide atau rancangan dari matematika harus dikuasai dalam proses belajar mengajar. Matematika sebagai salah satu disiplin ilmu yang diajarkan pada setiapjenjang pendidikan 
sekolah, diharapkan dapat memberikan sumbangan dalam rangka mengembangkan kemampuan berpikir secara kritis, sistematis, logis, kreatif, dan bekerja sama secara efektif(Davidson et al., 1988).Andaikan penafsiran konsepnya rendah, lalu akan menimbulkan dampak yang rendah bagi prestasi belajar matematika peserta didik. Sementara, kemampuan merupakan sebuah kesanggupan, kecakapan, kekuatan dalam berusaha dengan diri sendiri (Novitasari et al., 2019). Sehingga, dapat disimpulkan bahwa kemampuan (ability) adalah sebuah kecakapan atau potensi seorang individu dalam menguasai keahlian ketika dalam melakukan sebuah pekerjaan atau menilai sesuatu terhadap apa yang dilakukan oleh orang lain.Terbukti bahwa peningkatan kemampuan berpikir kritis matematis siswa yang memperoleh pembelajaran dengan pendekatan problem possing secara signifikan lebih baik dibandingkan pembelajaran konvesional (Sarimanah, 2017).

Selain penafsiran tersebut, kemampuan berpikir sangat penting dimiliki oleh peserta didik, yaitu kemampuan berpikir kritis peserta didik. Halpern (Fakhriyah, 2014) mengemukakan pendapatnya tentang berpikir kritis, dimana berkaitan dengan penggunaan keterampilan intelektual atau sebuah triktrik yang dapat meningkatkan sebuah kemungkinan untuk menghasilkan suatu dampak yang diinginkan.Teori Halpern tentang berpikir kritis didalamnya terdapat sebuah: pemahaman, pemikiran dan bahasa, menalar secara deduktif, menganalisis argumen, menguji hipotesis, kesesuaian dan ketidakpastian, pengumpulan suatu ketentuan, penyelesaian suatu kejadian, dan berpikir kreatif. Selain itu, terdapat penjelasan yang sangat menarik tentang berpikir kritis, penjelasan ini dikemukakan oleh (Facione et al., n.d.), yaitu: "berpikir kritis adalah suatu proses untuk menentukan apa yang harus diyakini dan dilakukan".Dalam penerapan model pembelajaran probing-prompting, dimana kemapuan berpikir kritis peserta didik sangat disarankan untuk digunakan dalam proses pembelajaran disekolah (Susanti, 2017).

Sedangkan, menurut Masson (Facione et al., n.d.) dimana ia menyatakan: “ The conceptof critical thinking maybe one of the mosts ignificat trends in education relative to the dynamic relationship between how teachers teachand how students learn" berarti bahwa, berpikir kritis bisa saja menjadi sebuah kecondongan yang paling menonjol dalam pendidikan pada suatu hubungannya, dimana bagaimana guru mengajar dan bagaimana peserta didik belajar. Menurut dari pernyataan tersebut, sudah menjadi tugas dan kewajiban guru untuk mengembangankan kemampuan berpikir kritis peserta didik dalam sebuah pembelajaran yang bertujuan untuk mengasah kemampuan guru yang mengajar baik terhadap kemampuan peserta didik dalam belajar.Proses berpikir berkaitan erat dengan apa yang terjadi di dalam otak manusia, berpikir berkaitan dengan fakta-fakta yang ada dalam dunia, berpikir mungkin bisa divisualisasikan, dan berpikir (manakala diekspresikan) bisa diobservasi dan dikomunikasikan (Karim, 2011). Krulik dan Rudnick (Sarimanah, 2017) mengklarifikasikan keterampilan berpikir ke dalam empat tingkat, yaitu: 1) Menghafal (recall thinking), 2) Dasar (basic thinking), 3) Kritis (critical thinking), 4) Kreatif (creative thinking). King dan Goodson (Muliana, 2016) menyatakan bahwa kemampuan berpikir kritis merupakan salah satu tujuan dalam pembelajaran matematika. 
Oleh karena itu, kemampuan berpikir kritis peserta didik sangtlah penting dimiliki oleh peserta didik dan harus dimiliki agar dapat menghadapi berbagai permasalahan personal maupun sosial dalam kehidupannya (Nuryanti et al., 2018). Berdasarkan hasil obeservasiyang dilakukan peneliti di SMK Negeri 1 Polewali, bahwa kemampuan berpikir kritis peserta didik masih tergolong rendah dikarenakan banyaknya peserta didik masih bingung dalam menentukan rumus yang mana yang harus digunakan. Hal ini dapat menyebabkan berubahnya nilai KKM peserta didik yang dulunya 70 sekarang menjadi 60 . Dengan belajar online, peserta didik juga akan sulit memahami materi, sehinggadapat mempengaruhi hasil belajar peserta didik nantinya. Rendahnya hasil pembelajaran matematika diduga disebabkan karena kurang tepatnya metode atau model pembelajaran yang diterapkan oleh pendidik, proses belajar mengajar yang masih didominasi oleh guru, di mana guru sebagai sumber pengetahuan, dan kurangnya media pembelajaran.Untuk kurang tepatnya metode atau model pembelajaran, dimana guru masih menggunakan model pembelajaran konvensional dan tidak divariasikan dengan model yang lain, proses belajar mengajar seperti ini membuat peserta didik kurang termotivasi dengan penerapan pembelajaran.

Bertolak dari penjelasan mengenai konsep matematika perlu di tekankan kepada peserta didik mengenai penggunaan model pembelajaran CUPs pada pelajaran matematika, maka di perlukan proses kemampuan berpikir kritis agar mampu memahami model tersebut. Berdasarkan penelitian Prastiwi dkk (Prastiwi, 2014) dijelaskan bahwa model pembelajaran Conceptual Understanding Procedures (CUPs) dapat dijadikan sebuah alternatif peserta didik untuk berperan aktif dalam suatu proses pembelajaran dan juga berperan kreatif dalam menentukan sebuah solusi untuk memecahkan suatu permasalahan. Sementara hasil peneliti lain menyatakan bahwa, melalui model pembelajaran CUPs dapat menghasilkan kemampuan pemahaman konsep yang lebih baik dibandingkan dengan penggunaan model pembelajaran langsung (Salsabila, 2019). Selain itu, terdapat hasil penelitian dari Kartikawati dan Pratama (Pertiwi, 2018) menunjukkan dimana penggunaan WhatsApp Messenger sebagai mobile learning terintegrasi metode group investigation efektif untuk diterapkan dalam proses pembelajaran dalam upaya meningkatkan kemampuan berpikir kritis peserta didik.

Jadi, model pembelajaran CUPs ini pertama kali dikembangkan oleh Richard F. Gunstone dari Universitas Monash, Australia dengan sebuah Project for Enhancing Learning (PEEL) dan kembali dikembangkan oleh David Mills dan Susan Feteris (School of Physicsand Materials Engineering at Monash University) beserta Pam Mulhalldan B. Mckittirik (Faculty of Education) pada tahun 1996. Menurut (Fay, 1967), mengemukakan bahwa "Model pembebelajaran Conceptual Understanding Procedures (CUPs) adalah suatu model pembelajaran yang bertujuan untuk membantu meningkatkan pemahaman konsep yang dianggap sulit oleh peserta didik". Sedangkan, (P \& Hidayati, 2015) mengemukakan bahwa model CUPs merupakan model pembelajaran yang didalamnya terdapat sebuah tuorial yang dibuat untuk meningkatkan suatu wawasan konsep yang dianggap sulit bagi peserta didik. Selain itu, dalam penerapan model pembelajaran PACE (Project Activity Cooperative Exercies) dengan menggunakan Kemampuan Berpikir Kreatif dan Komunikasi Matematis peserta didik bahwa model 
pembelajaran yang digunakan lebih tinggi dibandingkan dengan model pembelajaran Konvesional (Assaibin., 2020).

Sementara itu, model CUPs ialah suatu model pembelajaran yang berlandaskan pada sebuah pendekatan konstruktivisme (Goleman, Daniel; Boyatzis, Richard; Mckee \& Perdana, 2018). Dimana pendekatan ini, didasari oleh suatu keyakinan bahwa peserta didik dapat menyusun suatu pemahaman konsep dengan menyebarkan ilmu pengetahuan yang sudah ada. Adapun sintaks dari model pembelajaran CUPs yag dikemukakan oleh Gunstone (Arsyad, 2017), yakni:

1. Fase Individual (Individual Phase).

2. Fase Triplet (Triplet Phase).

3. Fase Diskusi Interperatif Seluruh Kelas (Whole Class Interpretive Discussion).

Model CUPs merupakan pembelajaran kooperatif yang artinya mengerjakan sesuatu secara berkelompok dengan saling membantu satu sama lainnya sebagai satu tim (Saregar et al., 2016). Pembelajaran kooperatif adalah sistem pembelajaran yang berusaha memanfaatkan teman sejawat (peserta didik lain) sebagai sumber belajar, di samping pendidik dan sumber belajar lainnya (Munawaroh et al., 2012).

Terdapat keterampilan dan kemampuan dasar dalam berpikir kritis(Ennis, 1987), yaitu:

1. Klarifikasi menginterprestasi

Pada keterampilan ini, dibagi menjadi beberapa jenis, yakni: (1) Merumuskan masalah, (2) Mendefenisikan masalah, (3) Mengidentifikasi asumsi, (4) Mengkategorikan, (5) Menjelaskan siginfikasi, dan (6) Menjelaskan makna.

2. Menganalisis

Pada keterampilan menganalisis, juga terbagi menjadi 3 jenis, yaitu: (1) Memeriksa ide, (2) Mengidentifikasi argumen, dan (3) Mengidentifikasi alasan.

3. Membuat inferensi

Pada keterampilan membuat inferensi, terbagi menjadi 3 jenis, yaitu: (1) Mempertanyakan bukti, (2) Menduga beberapa alternatif, dan (3) Menarik kesimpulan secara deduktif atau induktif.

4. Mengevaluasi

Pada keterampilan mengevalusi, terbagi menjadi 3 jenis, yaitu: (1) Menyatakan hasil, (2) Justifikasi prosedur, dan (3) Memberikan alasan.

5. Mengatur diri

Yang terakhiri adalah keterampilan mengatur diri, dibagi menjadi 2 jenis, yaitu memonitor diri dan mengkoreksi diri.

Berdasarkan penjelasan diatas, disimpulkan bahwa indikator kemampuan berpikir kritis peserta didik, ialah: (1) Klarifikasi menginterprestasi, (2) Menganalisis, (3) Membuat inferensi, (4) Mengevaluasi, dan (5) Mengatur diri. Dalam penelitian "Perbandingan Kemampuan Menyelesaikan Masalah Matematika Pada Peserta Didik Laki-Laki dan Perempuan" dijelaskan bahwa suatu kemampuan yang harus dimiliki peserta didik adalah sebuah kemampuan pemecahan masalah (Problem 
Solving), penalaran (reasoning), dan berpikir kritis (critical thingking) merupakan sebuah tujuan kritis (critical gol) dalam suatu pembelajaran matematika (Kelas et al., 2018). Hal penting lainnya menurut Ennis (Facione et al., n.d.) dalam berpikir kritis dimana difokuskan ke dalam pengertian tentang sesuatu yang dilakukan dengan penuh kesadaran dan mengarah pada sebuah tujuan. Dimana salah satu tujuan utama yang sangat penting adalah untuk membantu seseorang membuat suatu keputusan yang tepat dan terbaik dalam hidupnya.Penguasaan kemampuan berpikir kritis tidak cukup dijadikan sebagai tujuan pendidikan semata, tetapi juga sebagai proses fundamental yang memungkinkan siswa untuk mengatasi berbagai permasalahan masa mendatang di lingkungannya (Matematika et al., 2014).

\section{METODE}

Jenis penelitian ini menggunakan jenis penelitian eksperimen semu (Quasy Experimen), sebab penelitian ini melibatkan 2 kelas yang dipilih secara acak sederhana. Kedua kelas tersebut, ialah kelas eksperimen dan kelas kontrol. Tujuan dilakukan penelitian ini yakni melihat perbedaan kemampuan berpikir kritis peserta didik melalui model pembelajaran CUPs pada kelas eksperimen dan model pembelajaran Konvesional pada kelas kontrol peserta didik kelas XII SMK Negeri 1 Polewali.

\section{Desain Penelitian}

Adapun bentuk desai penelitian yang digunakan, yaitu sebagai berikut:

\begin{tabular}{|c|c|c|}
\hline$O_{1}$ & $\mathrm{X}$ & $O_{2}$ \\
\hline$O_{2}$ & - & $O_{4}$ \\
\hline
\end{tabular}

Gambar 1. Desain Penelitian

Keterangan:

$O_{1}=$ Pemberian tes awal pada kelas eksperimen .

$\mathrm{O}_{2}=$ Pemberian tes awal pada kelas kontrol.

$\mathrm{X}=$ Implementasi model pembelajaran CUPs pada kelas eksperimen.

$\mathrm{O}_{2}=$ Pemberian tes akhir pada kelas eksperimen.

$\mathrm{O}_{4}=$ Pemberian tes akhir pada kelas kontrol.

\section{Instrumen Penelitian}

Intrumen penelitian yang diperlukan pada penelitian ini, yaitu:

1. Tes kemampuan berpikir kritis melalui model pembelajaran Conceptual Understanding Procedures (CUPs). Jika memenuhi kriteria, yakni:

a. Jika perolehan skor keseluruhan untuk tes akhir peserta didik mencapi nilai KKM sebesar 60, atau berada pada kategori baik.

b. Ketuntasan secara klasikal sebesar $60 \%$.

2. Lembar Aktivitas peserta didik dalam pembelajaran. Kemampuan berpikir kritis peserta didik melalui implementasi model pembelajaran CUPs berada pada kriteria tinggi dalam pembelajaran matematika, apabila aktivitas peserta didik mencai $\geq 65 \%$ (aktif). Tetapi, apabila aktivitas peserta didik $<65 \%$ (tidak aktif), berarti aktivitas peserta didik berada pada kriteria rendah. 
3. Lembar Angket respon peserta didik. Apabila jika respon peserta didik yang diberikan mencapai $\geq$ $75 \%$ dalam kategori mayoritas peserta didik merespon positif. Tetapi, jika nilai presentase $<75 \%$ yang merespon positif, respon peserta didik dikatakan tidak efektif.

4. Lembar keterlaksanaan pembelajaran. penyusunan pembelajaran dikatakan efektif, apabila jika skor atau nilai rata-rata aktvitas guru sedikitnya mencapai kriteria baik, yaitu $70 \%$.

\section{Teknik Pengumpulan Data}

Metode pengumpulan data yang diperlukan, ialah:

1. Kemampuan Berpikir Kritis. Instruman yang digunakan oleh peneliti yakni sebuah tes yang diberikan untuk kedua kelas, ialah tes awaldan tes akhir.

2. Lembar Observasi Aktivitas Peserta Didik. Metode pengumpulan data ini dilakukan dengan memakai lembar observasi aktivtas melalui pengematan aktivtas peserta didik.

3. Respon Peserta Didik. Metode pengumpulan data ini menggunakan angket respon peserta didik.

4. Keterlaksanaan Pembelajaran. Metode pengumpulan data ini menggunakan lembar keterlaksanaan pembelajaran oleh guru (peneliti).

\section{HASIL DAN PEMBAHASAN}

\section{Analisis Statistik Deskriptif}

\section{Hasil Analisis Pre-Test}

Hasil analisis statistik deskriptif pada pre-test Kemampuan Berpikir Kritis peserta didik melalui model pembelajaran Conceptual Understanding Procedures (CUPs) pada kelas eskperimen dan model Konvesional pada kelas kontrol.

Berdasarkan jumlah peserta didik sebanyak 30 orang peserta didik pada kelas eksperimen, menunjukkan bahwa kemampuan berpikir kritis peserta didik melalui model pembelajaran Conceptual Understanding Procedures (CUPs) didapat rerata (Mean) yang berjumlah 37,93. nilai tengah (Median) berjumlah 38,70. Untuk modus (mode) berjumlah 28,70. Standar deviasi (Std. Deviation) berjumlah 9,78. Variansi (variance) berjumlah 95,69. Jarak (range) merupakan nilai maksimum dikurangi dengan nilai minimum, kemudian interval dengan perolehan 31,70. Nilia terendah (minimum) yang didapat peseta didik sebesar 20,00. Sementara itu, nilai tertinggi (maximum) yang didapat peserta didik sebesar 51,70 .

Sementara itu, pada kelas kontrol dengan model pembelajaran Konvesional yang melibatkan 24 peserta didik, membuktikan bahwa hasil pre-test kemampuan berpikir kritis peserta didik dengan perolehan rata-rata (mean) yang berjumlah 37,14. Dengan nilai tengah (Median) berjumlah 38,70. Untuk nilai modus (mode) berjumlah 45,70. Standar deviasi (Std. Deviation) diperoleh sebesar 10,48. Variansi (variance) diperoleh sebesar 38,08. Jarak/interval (range) sebesar 110,00 dengan perolehan dari hasil pengurangan nilai maksimum dengan nilai minimum 35,72. Nilai terendah (minimum) diperoleh sebesar 15,70. Sementara itu, nilai tertinggi (maximum) diperoleh sebesar 51,42. 
Kemampuan Berpikir Kritis Peserta Didik Dalam Model Pembelajaran (CUPs) Matematika SMK Negeri 1 Polewali, Muhammad Assaibin, Muhammad Ali P, Ayu Rahayu Elviana

Tabel 1. Deskripsi Ketuntasan Tes Kemampuan Berpikir Kritis Peserta Didik untuk PreTest (Tes Awal) pada Kelas Eksperimen dan Kelas Kontrol

\begin{tabular}{|c|c|c|c|c|c|}
\hline \multirow{2}{*}{ Interval } & \multirow{2}{*}{ Kriteria } & \multicolumn{2}{c|}{ Kelas Eksperimen } & \multicolumn{2}{c|}{ Kelas Kontrol } \\
\cline { 2 - 6 } & & $\boldsymbol{F i}$ & $\mathbf{( \% )}$ & $\boldsymbol{f i}$ & $\mathbf{( \% )}$ \\
\hline $60<\mathrm{x} \leq 100$ & Tuntas & - & - & - & - \\
\hline $0<\mathrm{x} \leq 60$ & Tidak Tuntas & 30 & $100 \%$ & 24 & $100 \%$ \\
\hline \multicolumn{2}{|c|}{ Jumlah } & 30 & $100 \%$ & 24 & $100 \%$ \\
\hline
\end{tabular}

Tabel diatas menunjukkan skor ketuntasan tes kemampuan berpikir kritis peserta didik dengan mengaplikasikan model pembelajaran CUPs pada kelas eksperimen, bahwa secara keseluruhan peserta didik dengan frekuensi 30 dari 30 peserta didik berada pada kriteria tidak tuntas dengan presentase 100\%. Sementara itu pada kelas kontrol dengan mengaplikasikan model pembelajaran Konvesional, bahwa secara keseluruhan peserta didik dengan jumlah frekuensi 24 dari 24 peserta didik tidak memenuhi kriteria ketuntasan juga dengan presentase sebesar $100 \%$.

Sehingga, disimpulkan bahwa hasil tes kemampuan berpikir kritis peserta didik melalui pretest, baik itu kelas eksperimen dan kelas kontrol tidak mencapi kriteria ketuntasan klasikal, yaitu 60\%. Sementara itu dilihat dari hasil jawaban pretest, indikator kemampuan berpikir kritis peserta didik hanya 3 yang paling sering muncul, yaitu klarifikasi menginterprestasi, membuat inferensi, dan mengevaluasi baik itu hasil jawaban dari peserta didik kelas eksperimen ataupun dari kelas kontrol.

\section{Hasil Analisis Tes Akhir}

Perolehan analisis statistik deskriptif pada post-test Kemampuan Berpikir Kritis peserta didik melalui model pembelajaran CUPs terhadap kelas eskperimen dan model Konvesional pada kelas kontrol. Dilihat dari jumlah peserta didik pada kelas eksperimen sebanyak 30 orang dengan hasil posttest menujukkan bahwa kemampuan berpikir kritis peserta didik melalui model pembelajaran Conceptual Understanding Procedures (CUPs) pada kelas eksperimen memperoleh rerata (mean) sejumlah 80,13. Nilai tengah (median) berjumlah 80,50. Nilai modus (mode) berjumlah 65,00. Standar deviasi dengan perolehan 11,17. Variansi (variance) data diperoleh dengan jumlah 124,87. Interval (range) yang merupakan nilai terbesar dikurangi dengan nilai terkecil, kemudian diperoleh interval syang berjumlah 38,00. Untuk nilai terendah (minimum) dengan perolehan peserta didik sebesar 60,00. Sementara itu, untuk nilai tertinggi (maximum) peserta didik diperoleh sebesar 98,00.

Sedangkan pada kelas kontrol sebanyak 24 orang peserta didik dengan mengaplikasikan model pembelajaran Konvesional, membuktikan bahwa hasil kemampuan berpikir kritis peserta didik melalui posttest memperoleh nilai rata-rata (mean) sejumlah 73,50 , dengan perolehan nila tengah (median) sejumlah75,00. Sementara itu, nilai modus (mode) memperoleh 45,70. Standar deviasi (Std. Deviation) dengan perolehan 10,48. Variansi (variance) sejumlah 38,08. Jarak/interval (range) sebesar 110,00 yang ditemukan dari hasil pengurangan nilai maksimum dengan nilai minimum 35,72. Nilai minimum dengan perolehan 15,70. Sementara itu, untuk nilai maksimum diperoleh sebesar 51,42. 
Tabel 2. Deskripsi Ketuntasan Tes Kemampuan Berpikir Kritis Peserta Didik untuk Post Test (Tes Awal) pada Kelas Eksperimen dan Kelas Kontrol.

\begin{tabular}{|c|c|c|c|c|c|}
\hline \multirow{2}{*}{ Interval } & \multirow{2}{*}{ Kriteria } & \multicolumn{2}{c|}{ Kelas Eksperimen } & \multicolumn{2}{c|}{ Kelas Kontrol } \\
\cline { 3 - 6 } & & $\boldsymbol{F i}$ & $\mathbf{( \% )}$ & $\boldsymbol{f i}$ & $\mathbf{( \% )}$ \\
\hline $60<\mathrm{x} \leq 100$ & Tuntas & 30 & $100 \%$ & 20 & $83,33 \%$ \\
\hline $0<\mathrm{x} \leq 60$ & Tidak Tuntas & - & - & 4 & $16,67 \%$ \\
\hline \multicolumn{2}{|c|}{ Jumlah } & 30 & $100 \%$ & 24 & $100 \%$ \\
\hline
\end{tabular}

Tabel diatas menujukkan bahwa, daya berpikir kritis peserta didik melalui model pembelajaran CUPs pada kelas eksperimen, dimana nilai peserta didik berada pada kriteria tuntas sebanyak 30 orang dengan presentase sebesar $100 \%$. Sedangkan pada kelas kontrol, daya berpikir kritis peserta didik melalui model pembelajaran Konvesional, dimana peserta didik yang memenuhi kriteria tuntas sebanyak 20 orang dengan presentase sebesar $83,88 \%$ dan 4 orang diantaranya berada pada kriteria tidak tuntas dengan presentase sebesar $16,67 \%$.

Dari penjelasan diatas, bahwa determinasi hasil tes Kemampuan Berpikir Kritis peserta didik dengan menerapkan model pembelajaran CUPs pada kelas XII Adm. Perkantoran 1 (eksperimen) dan model pembelajaran Konvesional pada kelas XII Adm. Perkantoran 2 (kontrol) mempunyai hasil yang berbeda. Dimana kelas XII Adm. Perkantoran 1 (kelas eksperimen) yang telah diberikan percobaan Kemampuan Berpikir Kritis dengan mengimplementasikan model pembelajaran CUPs lebih baik daripada kelas XII Adm. Perkantoran 2 (kelas kontrol) dengan mengimplementasikan model pembelajaran Konvesional. Hal ini dapat dilihat dari hasil posttest yang diperoleh peserta didik, dimana kelas XII Adm. Perkantoran 1 memperoleh frekuensi 30 dari 30 peserta didik dengan presentase sebesar 100\% dan mencapai kriteria ketuntasan klasikal, yaitu sebesar 60\%. Sedangkan pada kelas XII Adm. Perkantoran 2, memperoleh frekuensi 20 dari 24 peserta didik dengan presentase sebesar 83,33\% dan juga mencapai kriteria tuntas, yaitu sebesar $60 \%$.

Sementara itu, dilihat dari indikator kemampuan berpikir kritis peserta didik dari hasil posttest kelas eksperimen, bahwa kemampuan berpikir kritis peserta didik meningkat dengan memunculkan 4 indikator, yaitu klarifikasi menginterprestasi, menganalisis, membuat inferensi, dan mengevaluasi. Sementara itu di kelas kontrol, kemampuan berpikir kritis peserta didik hanya beberapa peserta didik yang meningkat, tetapi lebih dominan hanya memunculkan 3 indikator kemampuan berpikir kritis, yakni klarifikasi menginterprestasi, membuat inferensi, dan mengevaluasi.

\section{Analisis Staistik Inferensial}

\section{Uji Normalitas}

1. Uji Normalitas Pre-Test

Tabel 3. Hasil Uji Normalitas pada Kelas Eksperimen dan Kelas Kontrol untuk PreTest (Tes Awal)

Test of Normality

\begin{tabular}{|ll|c|c|c|}
\hline \multirow{2}{*}{ Keterangan } & \multicolumn{3}{|c|}{ Kolmogorov-Smirnov $^{\mathbf{a}}$} \\
\cline { 3 - 5 } & Statistic & Df & Sig. \\
\hline \multirow{2}{*}{ Pretest } & Kelas Eksperimen & .157 & 24 & .131 \\
\cline { 3 - 5 } & Kelas Kontrol & .163 & 24 & .097 \\
\hline
\end{tabular}


Kemampuan Berpikir Kritis Peserta Didik Dalam Model Pembelajaran (CUPs) Matematika SMK Negeri 1 Polewali, Muhammad Assaibin, Muhammad Ali P, Ayu Rahayu Elviana

Dari tabel diatas, bahwa tiap-tiap dari data nilai test awal kelas eksperimen dan kelas kontrol memperoleh 0,131 dan 0,097. Yang berarti data dari kedua kelas untuk tes awal berada di kategori yang berdistribusi normal, sebab nilai sig $\alpha>0,05$ ialah $(0,013>0,05)$ bagi kelas eksperimen dan $(0,097>$ 0,05) bagi kelas kontrol.

\section{Uji Normalitas Post-Test}

Tabel 4. Hasil Uji Normalitas pada Kelas Eksperimen dan Kelas Kontrol untuk PostTest (Tes Akhir)

Tests Of Normality
\begin{tabular}{|cc|c|c|c|}
\hline \multirow{2}{*}{\multicolumn{2}{|c|}{ Keterangan }} & \multicolumn{3}{c|}{ Kolmogorov-Smirnov } \\
\cline { 3 - 5 } & Statistic & Df & Sig. \\
\hline \multirow{2}{*}{ Post Test } & Kelas Eksperimen & .128 & 24 & $.200^{*}$ \\
\cline { 2 - 5 } & Kelas Kontrol & .157 & 24 & .129 \\
\hline
\end{tabular}

Dari tabel diatas, ditemukan bahwa nilai tes akhir dengan taraf sig bagi kelas eskperimen memperoleh 0,200 dan nilai sig bagi kelas kontrol memperoleh 0,129. Maka dapat disimpulkan bahwa data kelas eksperimen dan kelas kontrol berdistribusi normal, karena nilai signifikansinya $\alpha>0,05$ atau $\mathrm{H}_{0}$ diterima.

\section{Uji Homogenitas}

1. Uji Homogenitas tes awal

Tabel 5. HasilUji Homogenitas terhadap Data PreTest (Tes Awal) bagi Kelas Eksperimen dan Kelas Kontrol

\begin{tabular}{|c|c|c|c|}
\hline \multicolumn{4}{|c|}{ Test of Homogeneity of Variances } \\
Nilai Pre Test Kedua Kelas \\
\hline Levene Statistic & df1 & df2 & Sig. \\
\hline 1.278 & 1 & 40 & .265 \\
\hline
\end{tabular}

Berdasarkan tabel diatas, nilai signifikansi dari uji homogenitas diperoleh 0,265 hal ini menerangkan bahwa nilai sig $\alpha>0,05$ yakni $0,265>0,05$. Kesimpulannya bahwa tidak ada perbedaan nilai tes awal diantara kedua kelas (eksperimen dan kontrol) atau dapat dikatakan keduanya bervariansi sama (homogen).

2. Uji Homogenitas Tes Akhir

Tabel 6. Hasil Uji Homogenitas terhadap Data PostTest (Tes Akhir) pada Kelas Eksperimen dan Kelas Kontrol

\begin{tabular}{|c|c|c|c|}
\hline \multicolumn{4}{|c|}{ Test of Homogeneity of Variances } \\
Nilai Post Test Kedua Kelas \\
\hline Levene Statistic & df1 & df2 & Sig. \\
\hline .978 & 1 & 52 & .327 \\
\hline
\end{tabular}

Berdasarkan tabel diatas, didapat hasil analisis data tes akhir dari kelas eksperimen dan kelas kontrol dengan nilai sig 0,327. Hal ini membuktikan bahwa nilai signifikansi $\alpha>0,05$ ialah 0,327 $>0,05$. Dari penjelasan tersebut dambil simpulan bahwa keduanya bervariansi sama (homogen). 


\section{Uji Hipotesis}

Selepas dilakukan uji normalitas dan homogenitas, kelihatan bahwa hasil dari keduanya berdistribusi normal dan homogen, hingga dilanjutkan ke uji hipotesis. Pengujian hasil daya berpikir kritis peserta didik saat pembelajaran Matematika untuk tes akhir bagi kelas eksperimen dan kelas kontrol, uji ini dilakukan dengan mengaplikasikan program SPSS dimana menggunakan compare means independent sample t test.

Tabel 7. Hasil Uji Independent Sample t Test Kelas Eksperimen dan Kelas Kontrol Independent Samples Test

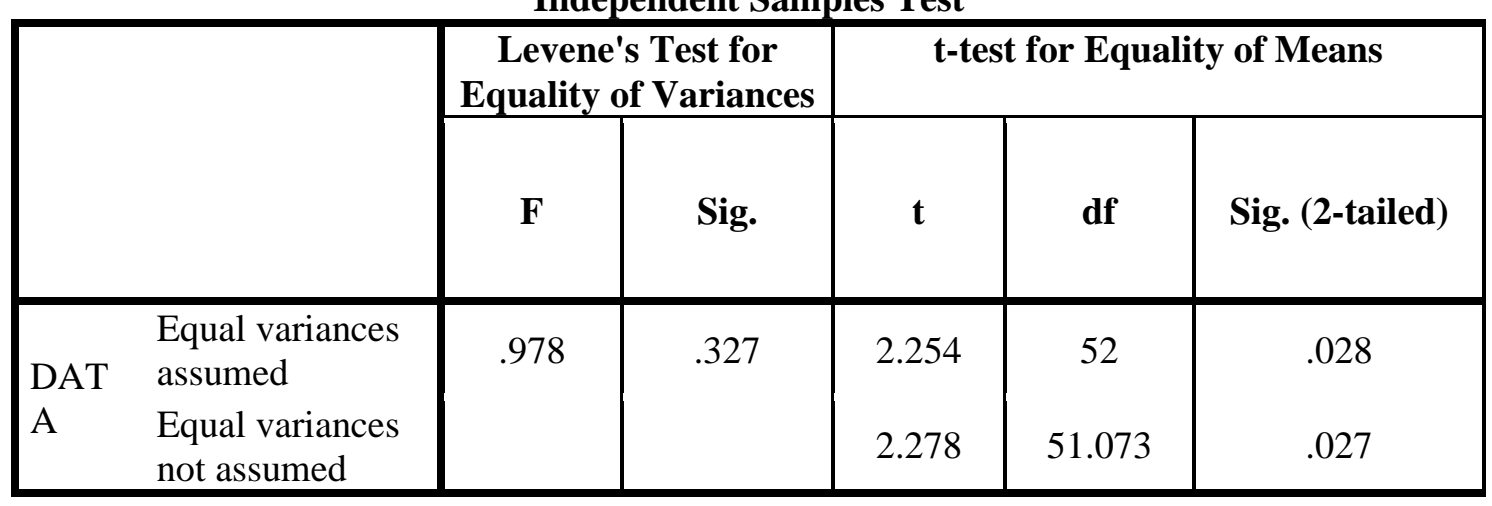

Berdasarkan tabel diatas, telah dilakukan uji hipotesis dengan mengimplementasikan uji t. Dimana uji-t ini memperoleh nilai $t_{\text {hitung }}$ sejumlah 2,254. Sementara itu nilai $t_{\text {tabel }}$ i sebesar 1,697 diartikan bahwa $t_{\text {hitung }}>t_{\text {tabel }}$ ialah 2,254 $\geq 1,697$. Dapat disimpulkan bahwa $H_{0}$ ditolak dan $H_{1}$ diterima. Bila dilihat dari taraf signifikansi $H_{1}$ diterima apabila $\operatorname{sig} \alpha<0,05$ yakni $0,028<0,05$. HIngga, dapat disimpulkan bahwa pembelajaran dengan mengimplementasikan Model Pembelajaan CUPs efektif terhadap kemampuan berpikir kritis peserta didik dalam pembelajaran Matematika Kelas XII SMK Negeri 1 Polewali.

\section{Hasil Analisis Aktivitas Peserta Didik}

\section{Hasil Analisis Aktivtas Peserta Didik Kelas Eksperimen}

Dari hasil analisis lembar aktivitas peserta didik, dari pertemuan pertama sampai pertemua kelima menunjukkan bahwa peserta didik yang mengerjakan soal diperoleh presentase sebesar 85,33\%. Peserta didik yang menyelesaikan tugas diperoleh presentase sebesar 74,66\%. Peserta didik yang mengerjakan tugas diperoleh presentase sebesar $80 \%$. Untuk peserta didik yang mengumpulkan tugas sebesar 91,33\%. Sedangkan, peserta didik yang memilih jawaban dalam proses diksusi sebesar 76,66\%. Sementara itu, peserta didik yang menanggapinya diperoleh sebesar 75,99\%. Dan untuk peserta didik yang memahami jawaban yang dipresentasekan sebesar 78,33\%. Sehingga, rerata dari aktivitas peserta didik pada kelas eksperimen secara keseluruhan aspek yang diamati diperoleh presentase sebesar 80,91\%. Yang berarti aktivitas peserta didik di kelas eksperimen dengan mengaplikasikan model pembelajaran CUPs efektif digunakan. 
Kemampuan Berpikir Kritis Peserta Didik Dalam Model Pembelajaran (CUPs) Matematika SMK Negeri 1 Polewali, Muhammad Assaibin, Muhammad Ali P, Ayu Rahayu Elviana

\section{Hasil Analisis Aktivtas Peserta Didik Kelas Kontrol}

Hasil analisis lembar aktivitas peserta didik kelas kontrol dari pertemuan pertama sampai pertemuan kelima, dapat dibuktikan bahwa peserta didik yang memperhatikan penjelasan guru diperoleh presentase sebesar $72,49 \%$. Peserta didik yang mengamati pemberian contoh diperoleh presentase sebesar $64,16 \%$. Untuk peserta didik yang membaca materi diperoleh $65,02 \%$. peserta didik yang menulis resume diperoleh presentase sebesar $72,5 \%$. Sedangkan, peserta didik yang mendengarkan penjelasan sebesar 67,5\%. Dan peserta didik yang menyimak diperoleh presentase sebesar 65,83\%. Ditinjau dari hasil analisis aktivitas peserta didik, bahwa nilai rata-rata dari semua aspek yang diamati pada kelas kontrol memperoleh nilai 67,92\%. Hasil ini membuktikan bahwa aktivitas peserta didik berada pada kategori aktif, hingga bagi kelas kontrol yang diberikan tindakan dengan model pembelajaran Konvesional efektif dilakukan.

\section{Hasil Analisis Lembar Keterlaksanaan Pembelajaran}

Hasil pengamatan keterlaksanaan pembelajaran selama proses proses pembelajaran berlangsung, dapat dilihat hasil analisis pembelajaran sebagai berikut ini:

1. Hasil Analisis Lembar Keterlaksanaan Pembelajaran Kelas Eksperimen

Tabel 8. Data Hasil Pengamatan Keterlaksanaan Pembelajaran peneliti Kelas Eksperimen

\begin{tabular}{|c|c|c|c|}
\hline No. & $\begin{array}{c}\text { Pertemuan } \\
\text { Ke- }\end{array}$ & $\begin{array}{c}\text { Frekuensi Keterlaksanaan } \\
\text { Pembelajaran }\end{array}$ & Persentase (\%) \\
\hline 1. & I & 17 & $80 \%$ \\
\hline 2. & II & 21 & $100 \%$ \\
\hline 3. & III & 21 & $100 \%$ \\
\hline 4. & IV & 21 & $100 \%$ \\
\hline 5. & V & 21 & $100 \%$ \\
\hline \multicolumn{2}{|c|}{ Jumlah } & $\mathbf{1 0 1}$ & $\mathbf{9 6 \%}$ \\
\hline
\end{tabular}

Berdasarkan dari hasil pengamatan diatas, dapat dilihat nilai rata-rata keterlaksanaan pembelajaran dari semua aspek yang diperhatikan, memperoleh presentase 96\%. Disimpulkan bahwa, keterlaksanaan pembelajaran bagi kelas eksperimen dengan mengimplementasikan model pembelajaran CUPs dari pertemuan pertama hingga pertemuan kelima berada pada kriteria sangat efektif, yaitu 96\% > 70\% atau dengan kata lain efelktif digunakan.

2. Hasil Analisis Lembar Keterlaksanaan Pembelajaran Kelas Kontrol

Tabel 9. Data Hasil Pengamatan Keterlaksanaan Pembelajaran peneliti Kelas Kontrol

\begin{tabular}{|c|c|c|c|}
\hline No. & $\begin{array}{c}\text { Pertemuan } \\
\text { Ke- }\end{array}$ & $\begin{array}{c}\text { Frekuensi Keterlaksanaan } \\
\text { Pembelajaran }\end{array}$ & Presentase (\%) \\
\hline 1. & I & 11 & $56 \%$ \\
\hline 2. & II & 16 & $85 \%$ \\
\hline 3. & III & 15 & $79 \%$ \\
\hline 4. & IV & 12 & $62 \%$ \\
\hline 5. & V & 13 & $68 \%$ \\
\hline \multicolumn{2}{|c|}{ Jumlah } & $\mathbf{6 7}$ & $\mathbf{7 0 \%}$ \\
\hline
\end{tabular}


Berdasarkan hasil analisis lembar keterlaksanaan pembelajaran diatas, dapat dilihat dari pertemuan pertama sampai pertemuan kelima diperoleh keseluruhan semua aspek yang diamati dengan presentase $70 \%$ yang berarti bahwa dari keseluruhan di setiap pertemuan di kelas kontrol dengan pengaplikasian model pembelajaran Konvesional masuk kedalamkariteria baik, yatu 70\% $<70 \%$.

\section{Hasil Analisis Angket Respon Peserta Didik}

\section{Hasil Analisis Angket Respon Peserta Didik Kelas Eksperimen}

Dari hasil analisis angket respon peserta didik kelas eksperimen, disimpulkan bahwa respon peserta didik terhadap prosep pembelajaran dengan menggunakan model pembelajaran Conceptual UnderstandingProcedures (CUPs) terhadap Kemampuan Berpikir Kritis, dengan perolehan rata-rata respon dari peserta didik lebih dominan memilih respon positif (favorable) dengan kriteria penafsiran hampir seluruhnya merespon positif, yaitu $75 \% \leq \mathrm{P}<100 \%$.

\section{Hasil Analisis Angket Respon Peserta Didik Kelas Kontrol}

Dari perolehan analisis angket respon peserta didik kelas kontrol disimpulkan bahwa respon peserta didik terhadap implementasi model pembelajaran konvesional dengan daya berpikir kritis dalam pembelajaran matematika, dimana peserta didik sebagian besar memilih respon negatif dan sebagian kecil memilih respon positif dengan kriteria penafsiran sebagian besar merespon negatif, yaitu $25 \%<\mathrm{P}$ $<50 \%$.

\section{Perbedaan Kemampuan Berpikir Krittis Peserta Didik Kelas Eksperimen dan Kelas Kontrol}

Tabel 10. Hasil PreTest dan PostTest Kelas Eksperimen dengan Model Pembelajaran CUPs dan Kelas Kontrol dengan Model Pembelajaran Konvesional

\begin{tabular}{|c|c|c|c|c|c|c|}
\hline \multirow{2}{*}{ Kelas } & \multicolumn{3}{|c|}{ PreTest } & \multicolumn{3}{c|}{ PostTest } \\
\cline { 2 - 7 } & $\bar{x}$ & Tuntas (\%) & $\begin{array}{c}\text { Tidak Tuntas } \\
(\%)\end{array}$ & $\bar{x}$ & Tuntas (\%) & $\begin{array}{c}\text { Tidak Tuntas } \\
(\%)\end{array}$ \\
\hline Eksperimen & 37,97 & - & $100 \%$ & 80,13 & $100 \%$ & - \\
\hline Kontrol & 37,14 & - & $100 \%$ & 73,50 & $83,88 \%$ & $16,67 \%$ \\
\hline
\end{tabular}

Berdasarkan tabel tersebut, bahwa kedua kelas sebelum diuji coba, dengan perolehan hasil rerata pretest kelas eksperimen lebih besar daripada kelas kontrol, tetapi presentase ketuntasannya sama sekali belum terdapat peserta didik yang tuntas pada pemberianpretest, hingga dapat dikatakan bahwa ketuntasan klasikal dari keduanya belum mencapai ketuntasan. Sementara itu, sesudah diuji coba pada kelas eksperimen dengan model pembelajaran CUPs dan kelas kontrol dengan model pembelajaran konvesional berdasarkan perolehan tes akhir ditunjukkan bahwa, rerata pada kelas eksperimen lebih besar dari pada kelas kontrol, begitupun dengan presentase ketuntasannya yang didapat. Sementara ditilik dari ketuntasan secara klasikal yang telah didelegasikan dalam penelitian ini ialah sebesar $60 \%$. Sementara itu jika diihat dari indikator kemampuan berpikir kritisnya dari hasil tes awal ataupun tes akhir, dimana yang hanya 4 idikator yang paling menonjol, yaitu klarifikasi menginterprestasi, menganalisis, membuat inferensi, dan mengevaluasi. Pada kelas eksperimen sudah mencapai $\alpha>60 \%$ yang berati bahwa ketuntasan secara klasikal pada kelas eksperimen telah terpenuhi secara kesuluruhan. 
Sedangkan pada kelas kontrol, dapat dilihat ketuntasan secara klasikalnya telah mencapai kriterian tuntas, tetapi hanya sebagaian kecil.

\section{KESIMPULAN}

Daya berpikir kritis peserta didik bagi kelas eksperimen mendapatkan rerata sejumlah 81,13. Sementara bagi kelas kontrol, daya berpikir kritis peserta didik memperoleh rerata 75,50. Jadi disimpulkan bahwa rerata kelas eksperimen dengan mengimplementasikan model pembelajaran CUPs lebih tinggi daripada penerapan model pembelajaran konvesional bagi kelas kontrol.Sementara pada hasil uji-t, dengan perolehan nilai $t_{\text {hitung }} 2,524$ dan untuk $t_{\text {tabel }}$ yakni 1,697 yang berarti bahwa $t_{\text {hitung }}>$ $t_{\text {tabel }}$ yaitu 2,534 > 1,697. Hal ini menunjukkan bahwa $H_{0}$ ditolak dan $H_{1}$ diterima. Ditinjau dari taraf signifikansi $H_{1}$ diterima apabila sig $\alpha<0,05$ yakni $0,028<0,05$. Hingga disimpulkan bahwa peserta didik yang diajarkan dengan model pembelajaran CUPs efektif terhadap kemampuan berpikir kritis peserta didik kelas XII SMK Negeri 1 Polewali.

\section{REFERENSI}

Arsyad. (2017). Bab II kajian teori. BAB 2 Kajian Teori, 1, 16-72.

Davidson, R. N., Lynn, W., Savage, P., \& Wansbrough-Jones, M. H. (1988). Chickenpox pneumonia: Experience with antiviral treatment. Thorax, 43(8), 627-630. https://doi.org/10.1136/thx.43.8.627

Ennis, R. H. (1987). A taxonomy of critical thinking disposition and abilities. In J. B. Baron \& R. J. Sternberg (Eds.), Teaching thinking skills: Theory and practice. New York, NY., 9-26.

Facione, P., Ann, C., Critically, T., Pdf, E., Critically, T., Download, E., Critically, T., Facione, P., Ann, C., Download, G., Online, R., \& Critically, T. (n.d.). [ PDF ] Think Critically ( 3rd Edition ). 3.

Fakhriyah, F. (2014). Penerapan problem based learning dalam upaya mengembangkan kemampuan berpikir kritis mahasiswa. Jurnal Pendidikan IPA Indonesia, 3(1), 95-101. https://doi.org/10.15294/jpii.v3i1.2906

Fay, D. L. (1967). 済無No Title No Title No Title. Angewandte Chemie International Edition, 6(11), 951-952., 11-33.

Goleman, Daniel; Boyatzis, Richard; Mckee, A., \& Perdana. (2018). Belajar Maatematika. Journal of Chemical Information and Modeling, 53(9), 1689-1699.

Karim, A. (2011). Penerapan metode penemuan terbimbing dalam pembelajaran matematika untuk meningkatkan pemahaman konsep dan kemampuan berpikir kritis siswa sekolah dasar. Seminar Nasional Matematika Dan Terapan, 29-38.

Prastiwi. (2014). Efektivitas Pembelajaran Conceptual Understanding Procedures Untuk Meningkatkan Kemampuan Siswa Pada Aspek Koneksi Matematika. Kreano: Jurnal Matematika KreatifInovatif, 5(1), 41-47. https://doi.org/10.15294/kreano.v5i1.3276

Ikhsan, M .Matematika, J. D., Pendidikan, M., Program, M., Universitas, P., Kuala, S., Aceh, B.,., Kuala, 
U. S., Rizal, S., \& Kuala, U. S. (2014). Penerapan Model Pembelajaran Berbasis Masalah untuk Meningkatkan Kemampuan Berpikir Kritis dan Disposisi Matematis Siswa. Jurnal Didaktik Matematika, 1(1), 71-82. https://doi.org/10.24815/jdm.v1i1.1243

Munawaroh, R., Subali, B., \& Sopyan, A. (2012). Penerapan Model Project Based Learning Dan Kooperatif Untuk Membangun Empat Pilar Pembelajaran Siswa SMP Info Artikel Abstrak. 1(2257).

Assaibin, M., \& Husain, R. (2020). Komunikasi Matematis Melalui Model Pace (Project Activity Cooperative Exercise) Siswa Kelas VIII SMP Negeri 1 Polewali. XI(2) No, V. X. I.,.

Novitasari, R., Nasirun, M., \& D., D. (2019). Meningkatkan Kemampuan Motorik Kasar Anak Melalui Bermain Dengan Media Hulahoop Pada Anak Kelompok B Paud Al-Syafaqoh Kabupaten Rejang Lebong. Jurnal Ilmiah POTENSIA, 4(1), 6-12. https://doi.org/10.33369/jip.4.1.6-12

Nuryanti, L., Zubaidah, S., \& Diantoro, M. (2018). Analisis Kemampuan Berpikir Kritis Siswa SMP. Jurnal Pendidikan: Teori, Penelitian, Dan Pengembangan2, 3(2), 155-158. http://journal.um.ac.id/index.php/jptpp/

Hidayati, F \& P, S. M. A. N. B. T. (2015). Pengaruh Model Pembelajaran Conceptual Understanding Procedures ( CUPs) Terhadap Hasil Belajar Siswa Pada Materi Pokok Listrik Dinamis Di Kelas X SEMESTER II. 3.

Pertiwi, W. (2018). Analisis kemampuan berpikir kritis matematika peserta didik SMK pada materi matriks. Jurnal Pendidikan Tamnusai, 2(4), 793-801.

Salsabila, F. (2019). Pengaruh Model Pembelajaran Conceptual Understanding Procedures (CUPs) Berbantuan Media Handout Terhadap Kemampuan Pemahaman Konsep Ditinjau Dari Gaya Belajar Di SMK N 3 Pekalongan. Delta: Jurnal Ilmiah Pendidikan Matematika, 7(1), 37. https://doi.org/10.31941/delta.v7i1.922

Saregar, A., Latifah, S., \& Sari, M. (2016). Efektivitas Model Pembelajaran CUPs: Dampak Terhadap Kemampuan Berpikir Tingkat Tinggi Peserta Didik Madrasah Aliyah Mathla'ul Anwar Gisting Lampung. Jurnal Ilmiah Pendidikan Fisika Al-Biruni, 5(2), 233-244. https://doi.org/10.24042/jpifalbiruni.v5i2.123

Sarimanah, T. (2017). Meningkatkan Kemampuan Berpikir Kritis Matematik Siswa Smp Melalui Pendekatan Problem Posing. Prisma, 6(2). https://doi.org/10.35194/jp.v6i2.123

Susanti, E. (2017). Penerapan Model Pembelajaran Probing-Prompting Untuk Meningkatkan Kemampuan Berpikir Kritis Matematis Siswa Kelas Xi.Ipa Man 1 Kota Bengkulu. Journal of Chemical Information and Modeling, 53(9), 1689-1699. 